\title{
Composition and diversity of benthic macroinvertebrates in a Brazilian Cerrado stream
}

\author{
Jéssica F. G. Pio (1), Eunice de F. E. Santiago (1) \& Carlos E. Copatti (i)
}

\begin{abstract}
Instituto de Biologia, Universidade Federal da Bahia. Rua Barão de Jeremoabo, 147, Campus de Ondina, $40170-290$ Salvador, BA, Brazil. (jessicapio_bio@yahoo.com.br; eunicefesantiago@hotmail.com; carloseduardocopatti@yahoo.com.br)
\end{abstract}

\author{
Received 12 July 2019 \\ Accepted 4 June 2020 \\ Published 15 July 2020 \\ DOI 10.1590/1678-4766e2020016
}

\begin{abstract}
This study aimed to analyse the diversity and composition of benthic macroinvertebrate assemblages in the dry and rainy seasons in a Brazilian Cerrado stream, where it was hypothesized that the dry season has higher diversity and it differs in terms of organism composition in relation to the rainy season. Sampling was carried out in the dry (May and August/2016 and August/2017) and rainy seasons (November/2016 and February and November/2017). Individuals were identified at the family level and classified according to functional feeding group (FFG). There were 3,776 individuals, in which Chironomidae was the most abundant taxon with 2,226 organisms. The FFG with the highest number of individuals and species richness were collector-gatherer and predator, respectively. The species richness was higher in the dry season than in the rainy season. The ordinance generated by NMDS showed that there was no distinction in the composition of the assemblage between the dry and rainy seasons. Seasonal variations do not alter the abundance and composition of the benthic macroinvertebrate assemblage, but the species richness does decrease in rainy seasons.
\end{abstract}

KEYWORDS. Abundance, Chironomidae, functional feeding group, seasonal variations, richness.

RESUMO. Composição e diversidade de macroinvertebrados bentônicos em um riacho do Cerrado brasileiro. Este estudo teve como objetivo analisar a diversidade e a composição da assembleia de macroinvertebrados bentônicos nas estações seca e chuvosa em um riacho do Cerrado Brasileiro, testando a hipótese que a estação seca tem maior diversidade e difere em termos de composição de organismos em relação a estação chuvosa. A coleta foi realizada em estações secas (maio e agosto/2016 e agosto/2017) e chuvosas (novembro/2016 e fevereiro e novembro/2017). Os indivíduos foram identificados em nível de família e classificados de acordo com o grupo funcional alimentar (GFA). Foram identificados 3.776 indivíduos, onde Chironomidae foi o táxon mais abundante com 2.226 organismos. O GFA com maior número de indivíduos e riqueza foram coletor-catador e predador, respectivamente. A riqueza de espécies foi maior na estação seca do que na estação chuvosa. A ordenação gerada pelo NMDS mostrou que não houve distinção na composição da assembleia entre as estações seca e chuvosa. Concluímos que variações sazonais não alteram a abundância e a composição da comunidade de macroinvertebrados bentônicos, mas a riqueza de espécies diminuiu na estação chuvosa.

PALAVRAS-CHAVE. Abundância, Chironomidae, Grupo funcional alimentar, variações sazonais, riqueza.

Organisms living in freshwater ecosystems, as benthic macroinvertebrates, present an important behavioural, morphological and physiological adaptations that allow for the colonisation of habitats under adequate conditions for their survival (Esteves et al., 2011; SAlles \& FerreiraJÚNIOR, 2014). In addition, they can be classified according to their functional feeding group (FFG), which follows variation in the amount or quality of suitable food or factors determining the distribution of food resources (WRIGHT \& LI, 2002). In this context, the use of taxonomic and ecological knowledge of these organisms in biomonitoring studies allows for the evaluation of the response of these organisms to environmental variables or even the evaluation of which food resource prevails in the system (KIKUCHI \& UIEDA, 2005).

Streams are generally influenced by natural disturbances, which in turn, vary in space and time (PEIRó \& Alves, 2006; Nessimian et al., 2008). Therefore, the hydrological dynamics that characterise periods of flood and drought determine the structure of benthic macroinvertebrate assemblages (LAKE, 2000). Such variations alter the habitat structure and habitat structure and determine the colonisation and establishment of benthic macroinvertebrates in lotic environments (Tundisi \& MATSUMURA-Tundisi, 2008; MeLo, 2009). In the rainy seasons, an increase in flow carries eroded particles from the soil of the basin, destabilising the substrate, reducing the number of habitats available, and causing the drag of organisms (DUDGEON \& WU, 1999; SilveIRA et al., 2006). In this scenario, therefore, the richness and abundance of benthic macroinvertebrates possibly be reduced. Conversely, in the dry season, the decrease of water flow reduces the current and increases the stability of the substrate, allowing for the establishment of organisms (BISPO et al., 2001; OliveIra \& NesSimian, 2001). 
Considering the importance of the benthic macroinvertebrates to environmental processes, there is still a lack of information about the structure of this community in streams of the Brazilian Cerrado. In this tropical ecosystem, the rainfall regime is well defined by dry winters, rainy summers, dry winters and sudden hydrological changes (Loвo, 2013). So, the objective of this study was to analyse the structure and composition of these macroinvertebrates of a stream in the Brazilian Cerrado in the dry and rainy seasons. It was hypothesised that, given the greater stability of the hydrologic regime, diversity indices of the benthic macroinvertebrates are higher during the dry season in comparison with the rainy season, and that the dry season differs in terms of organism composition in relation to the rainy season.

\section{MATERIAL AND METHODS}

Study sites. The study was conducted in the Das Fêmeas stream, São Desidério, BA, northeastern Brazil, which belongs to the Medium Rio São Francisco Basin. There is high agricultural occupation and marked deforestation in the surrounding areas. The ecosystem is as located in the Cerrado biome, in which the grasses coexist with gallery forests. The climate is classified as Aw in the Köppen system. The region has a mean annual rainfall above $1,100 \mathrm{~mm}$ and an average annual air temperature of $23.2^{\circ} \mathrm{C}$, with mean monthly temperatures between 16 and $31^{\circ} \mathrm{C}$ (Pimentel et al., 2000).

We selected four sampling sites distributed along the Das Fêmeas stream and distant approximately $1 \mathrm{~km}$ from each other (Fig. 1). All sampling sites presented preserved riparian vegetation, pristine conditions and a depth of up to $1 \mathrm{~m}$. In addition, sampling sites selected are perennial throughout the year, since many sites in the Das Fêmeas stream do not follow this pattern and flow underground during the dry season.

Sample design and identification. Sampling was carried out in May (dry season), August (dry season) and November (rainy season) in 2016 and February (rainy season), August (dry season) and November (rainy season) in 2017, with mean air temperatures and precipitation of 23.7, 24.7, 25.2, 25.5, 26.5 and $27.1^{\circ} \mathrm{C}$ and 3, 0, 110, 240, 0 and $225 \mathrm{~mm}$, respectively (INMET, 2017).

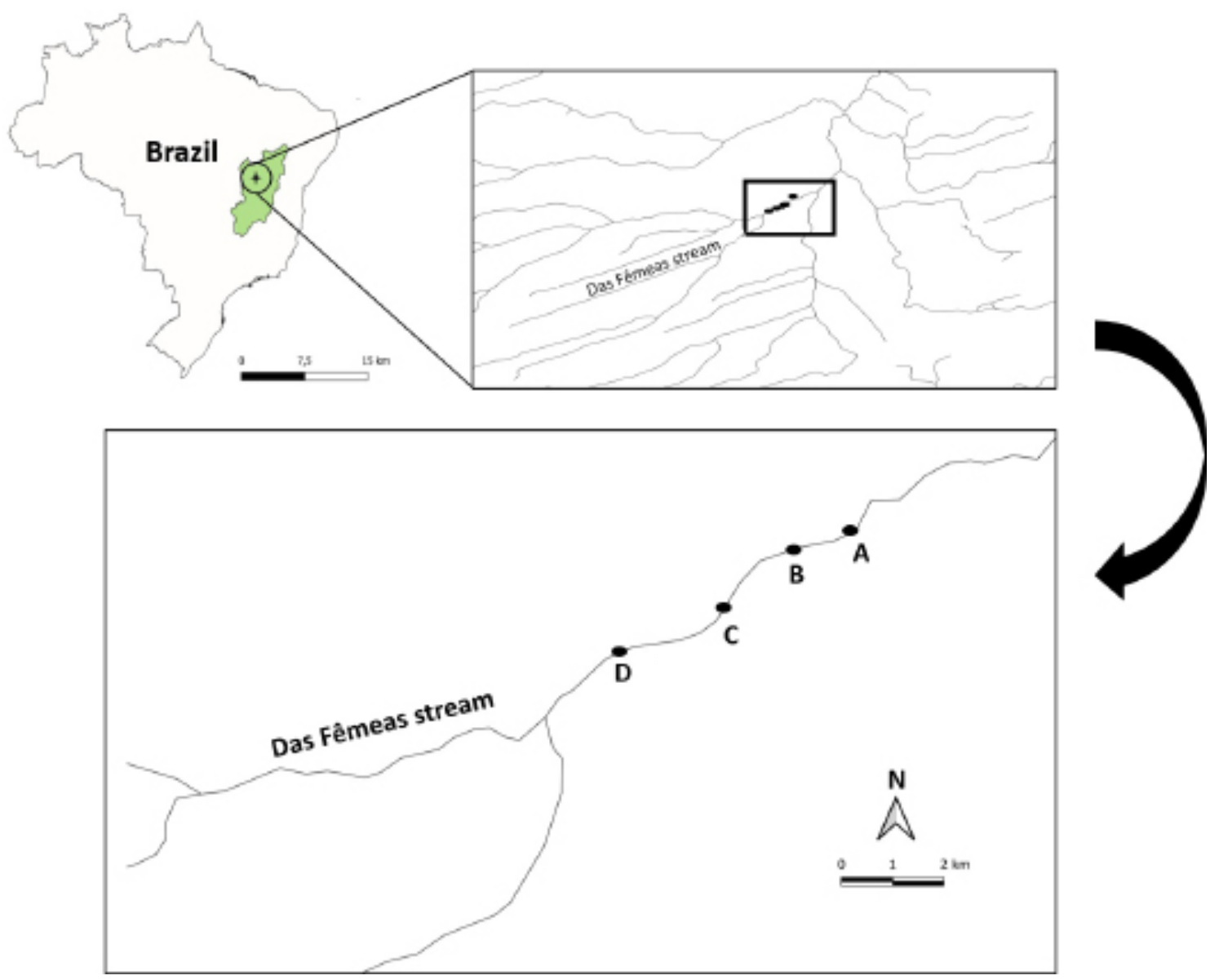

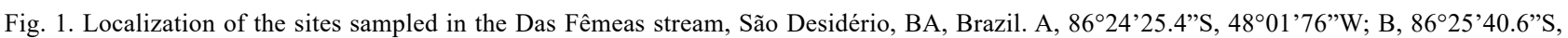

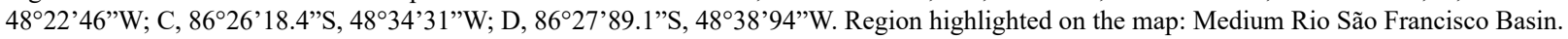


Benthic macroinvertebrates were collected from the margins using a network " D" support (0.25 mm mesh; $0.1 \mathrm{~m}^{2}$ area). A sample of stream sediment was carried out at each sampling point. At each sampling site, 10 sub-samples $\left(1 \mathrm{~m}^{2}\right.$ area) were sampled. The substrate was heterogeneous at all sampling sites with presence of sand, gravel, leaves and algae. The samples were placed in plastic containers and preserved in a $10 \%$ formaldehyde solution. Screening was performed in the Laboratory of Study and Physiology of Aquatic Fauna of the Universidade Federal da Bahia (LEFFA-UFBA), Brazil. The identified organisms were preserved in $80 \%$ ethanol. The specimens and their FFG were identified to the family level (except for Clitellata, which had been identified up to subclass), using the taxonomic keys of Cummins et al. (2005) and Domínguez \& FERnÁndeZ (2009).

Data analysis. Shannon-Wiener diversity index (H') base $\log 10$, Pielou equitability index (J'), total richness, rarefied richness and abundance of benthic macroinvertebrates were estimated, considering taxonomic uniformity at the family level. Additionally, abundance and richness of benthic macroinvertebrate food functional groups (FFG) were measured. Prior to analysis, abundance values were square-root transformed. The Levene test showed the homoscedasticity of the variances. To test the hypothesis that the dry season has a more distinct benthic macroinvertebrate assemblage than the rainy season, these data were analysed using a one-way analysis of variance (ANOVA), followed by a post hoc Tukey test. The significance level was set at $95 \%(\mathrm{p}<0.05)$.

Non-metric multidimensional scaling (NMDS) was chosen as the best method to represent most of the original information about the variation in benthic macroinvertebrate abundance obtained from the abundance data of each site ( $n=24$, dry and rainy seasons). As a metric of similarity among replicates, the Bray-Curtis distance was used as it incorporates abundance data and gives less weight to outliers. Two dimensions were selected, which were indicated as the most appropriate, and a Monte-Carlo test was used to check if the axis extracted from NMDS to represent the original matrix was stronger than expected by chance $(\mathrm{p}<0.05)$.
The analyses were performed with PC-ORD software v. 4.25 according PIO et al. (2018).

\section{RESULTS}

There were 3,776 individuals identified, distributed across three classes (Insecta, Clitellata and Gastropoda) and 36 taxa (Tab. I). Insecta was the most represented group (33 families, with 14 families occurring in all seasons). Insecta orders with the largest number of families were Diptera (6 families) and Trichoptera ( 6 families). Chironomidae was the most abundant taxon, representing $60 \%$ of all individuals. On the other hand, Corydalidae, Belostomatidae, Empididae, Ephemeridae and Psephenidae were each represented by only one individual (Tab. I).

The FFG with the highest number of individuals was collector-gatherer $(75.4 \%)$, followed by predator $(14.1 \%)$, filter-collector $(6.8 \%)$, shredder $(2.1 \%)$ and scraper $(1.5 \%)$. The FFG with greatest richness was predator (16 taxa), followed by collector-gatherer, filter-collector, shredder and scraper (8, 4, 4 and 4 taxa, respectively) (Tab. I). In general, FFG did not differ in abundance or richness between the seasons (except scraper, whose abundance was significantly higher in August 2016 than November 2016 and August 2017) $\left(\mathrm{F}_{1,5}=3.4 ; \mathrm{p}<0.046\right)$ (Fig. 2).

The abundance of individuals was significantly higher in August 2016 than in August $2017\left(\mathrm{~F}_{1,5}=3.7 ; \mathrm{p}=0.017\right)$. The total richness was significantly higher in August 2016 (dry season) than in February and November 2017 (rainy season) $\left(\mathrm{F}_{1,5}=3.4 ; \mathrm{p}=0.023\right)$. The $\mathrm{H}^{\prime}, \mathrm{J}$ ' and rarefied richness did not differ statistically between the seasons $(p>0.05)($ Tab. II).

The ordering of composition of benthic macroinvertebrates between seasons resulted in a minimal stress of 7.88, showing good quality in the ordination due to low distortion of the original data when reduced to a single axis. According to the Monte Carlo test, the axis extracted from NMDS was stronger than expected by chance $(\mathrm{p}=$ $0.003)$. The ordinance generated by NMDS showed that there was no distinction in the composition of the assemblage between the dry and rainy seasons (Fig. 3).

Tab. I. Benthic macroinvertebrates associated with different seasons in the Das Fêmeas stream, São Desidério, BA, Brazil (FFG, food functional group; $\mathrm{Cg}$, Collector-gatherer; Fc, Filter-collector; Sh, Shredder; Sc, Scraper; Pr, Predator). * Indicates significant difference between seasons ( $\mathrm{p}<0.05)$.

\begin{tabular}{|c|c|c|c|c|c|c|c|c|}
\hline Taxa & $\begin{array}{l}\text { May } \\
2016\end{array}$ & $\begin{array}{c}\text { Aug } \\
2016\end{array}$ & $\begin{array}{l}\text { Nov } \\
2016\end{array}$ & $\begin{array}{c}\text { Feb } \\
2017\end{array}$ & $\begin{array}{l}\text { Aug } \\
2017\end{array}$ & $\begin{array}{l}\text { Nov } \\
2017\end{array}$ & $\mathrm{~N}$ & FFG \\
\hline \multicolumn{9}{|l|}{ INSECTA } \\
\hline \multicolumn{9}{|l|}{ Coleoptera } \\
\hline Dytiscidae & 2 & 2 & 7 & 1 & 1 & 5 & 18 & $\operatorname{Pr}$ \\
\hline Elmidae & 73 & 36 & 14 & 4 & 7 & 0 & 134 & $\mathrm{Cg}$ \\
\hline Gyrinidae & 0 & 0 & 1 & 3 & 0 & 7 & 11 & $\operatorname{Pr}$ \\
\hline Hydrophilidae & 3 & 64 & 3 & 0 & 1 & 0 & 71 & $\operatorname{Pr}$ \\
\hline Psephenidae & 1 & 0 & 0 & 0 & 0 & 0 & 1 & $\mathrm{Sc}$ \\
\hline
\end{tabular}


Tab. I. Cont.

\begin{tabular}{|c|c|c|c|c|c|c|c|c|}
\hline Taxa & $\begin{array}{l}\text { May } \\
2016\end{array}$ & $\begin{array}{c}\text { Aug } \\
2016\end{array}$ & $\begin{array}{l}\text { Nov } \\
2016\end{array}$ & $\begin{array}{c}\text { Feb } \\
2017\end{array}$ & $\begin{array}{l}\text { Aug } \\
2017\end{array}$ & $\begin{array}{l}\text { Nov } \\
2017\end{array}$ & $\mathrm{~N}$ & FFG \\
\hline \multicolumn{9}{|l|}{ Diptera } \\
\hline Ceratopogonidae & 17 & 61 & 33 & 17 & 20 & 12 & 160 & $\operatorname{Pr}$ \\
\hline Chironomidae & 389 & 520 & 337 & 385 & 242 & 393 & 2266 & $\mathrm{Cg}$ \\
\hline Culicidae & 0 & 0 & 2 & 0 & 0 & 4 & 6 & $\mathrm{Sh}$ \\
\hline Empididae & 0 & 0 & 0 & 1 & 0 & 2 & 3 & $\operatorname{Pr}$ \\
\hline Simuliidae & 0 & 41 & 10 & 0 & 3 & 0 & 54 & $\mathrm{Cg}$ \\
\hline Tipulidae & 3 & 4 & 0 & 0 & 0 & 0 & 7 & Sh \\
\hline \multicolumn{9}{|l|}{ Ephemeroptera } \\
\hline Baetidae & 101 & 28 & 8 & 21 & 28 & 24 & 210 & $\mathrm{Cg}$ \\
\hline Caenidae & 0 & 2 & 0 & 0 & 0 & 0 & 2 & $\mathrm{Cg}$ \\
\hline Ephemeridae & 0 & 1 & 0 & 0 & 0 & 0 & 1 & $\mathrm{Cg}$ \\
\hline Leptohyphidae & 32 & 9 & 4 & 8 & 16 & 1 & 70 & $\mathrm{Cg}$ \\
\hline Leptophlebiidae & 45 & 12 & 6 & 1 & 14 & 33 & 111 & $\mathrm{Cg}$ \\
\hline \multicolumn{9}{|l|}{ Hemiptera } \\
\hline Belostomatidae & 0 & 1 & 0 & 0 & 0 & 0 & 1 & $\operatorname{Pr}$ \\
\hline Mesoveliidae & 0 & 1 & 4 & 1 & 0 & 0 & 6 & $\operatorname{Pr}$ \\
\hline Naucoridae & 7 & 2 & 12 & 16 & 5 & 2 & 44 & $\operatorname{Pr}$ \\
\hline Notonectidae & 36 & 3 & 26 & 0 & 0 & 0 & 65 & $\operatorname{Pr}$ \\
\hline \multicolumn{9}{|l|}{ Lepidoptera } \\
\hline Crambidae & 3 & 3 & 2 & 3 & 2 & 3 & 16 & $\mathrm{Sh}$ \\
\hline \multicolumn{9}{|l|}{ Megaloptera } \\
\hline Corydalidae & 0 & 1 & 0 & 0 & 0 & 0 & 1 & $\operatorname{Pr}$ \\
\hline \multicolumn{9}{|l|}{ Odonata } \\
\hline Calopterygidae & 0 & 1 & 0 & 0 & 4 & 0 & 5 & $\operatorname{Pr}$ \\
\hline Coenagrionidae & 3 & 11 & 8 & 2 & 4 & 8 & 36 & $\operatorname{Pr}$ \\
\hline Gomphidae & 0 & 3 & 3 & 0 & 0 & 0 & 6 & $\operatorname{Pr}$ \\
\hline Libellulidae & 9 & 24 & 7 & 1 & 9 & 8 & 58 & $\operatorname{Pr}$ \\
\hline \multicolumn{9}{|l|}{ Plecoptera } \\
\hline Perlidae & 0 & 1 & 1 & 0 & 0 & 0 & 2 & $\operatorname{Pr}$ \\
\hline \multicolumn{9}{|l|}{ Trichoptera } \\
\hline Helicopsychidae & 2 & 12 & 0 & 1 & 3 & 1 & 19 & $\mathrm{Sc}$ \\
\hline Hydropsychidae & 11 & 26 & 10 & 4 & 8 & 4 & 63 & $\mathrm{Fc}$ \\
\hline Hydroptilidae & 1 & 15 & 1 & 4 & 2 & 1 & 24 & $\mathrm{Sc}$ \\
\hline Leptoceridae & 7 & 12 & 1 & 13 & 9 & 4 & 46 & $\mathrm{Sh}$ \\
\hline Philopotamidae & 0 & 94 & 50 & 2 & 1 & 0 & 147 & $\mathrm{Fc}$ \\
\hline Polycentropodidae & 2 & 5 & 0 & 0 & 3 & 1 & 11 & $\mathrm{Fc}$ \\
\hline \multicolumn{9}{|l|}{ ANNELIDA } \\
\hline \multicolumn{9}{|l|}{ Clitellata } \\
\hline Hirudinea & 4 & 2 & 6 & 21 & 11 & 1 & 45 & $\operatorname{Pr}$ \\
\hline Oligochaeta & 10 & 10 & 1 & 7 & 11 & 3 & 42 & $\mathrm{Fc}$ \\
\hline \multicolumn{9}{|l|}{ MOLLUSCA } \\
\hline \multicolumn{9}{|l|}{ Gastropoda } \\
\hline Planorbidae & 7 & 5 & 2 & 0 & 0 & 0 & 14 & $\mathrm{Sc}$ \\
\hline Total individuals & 768 & 1012 & 559 & 516 & 404 & 517 & 3776 & \\
\hline Total Taxa & 23 & 32 & 26 & 21 & 22 & 20 & 36 & \\
\hline
\end{tabular}


Tab. II. Mean ( $( \pm$ SEM) for Shannon-Wiener diversity index (H'), Pielou equitability index (J'), abundance (N), total richness (S) and rarefied richness (E) of benthic macroinvertebrates in different seasons in the Das Fêmeas stream, São Desidério, BA, Brazil. * Indicates significant difference between seasons $(\mathrm{p}<0.05)$.

\begin{tabular}{lccccccc}
\hline Indexes & May 2016 & Aug 2016 & Nov 2016 & Feb 2017 & Aug 2017 & Nov 2017 \\
\hline H' $^{\prime}$ & $0.59 \pm 0.09$ & $0.74 \pm 0.07$ & $0.55 \pm 0.11$ & $0.45 \pm 0.06$ & $0.64 \pm 0.06$ & $0.43 \pm 0.06$ \\
J' & $0.57 \pm 0.10$ & $0.60 \pm 0.06$ & $0.49 \pm 0.06$ & $0.47 \pm 0.07$ & $0.62 \pm 0.06$ & $0.42 \pm 0.06$ \\
N & $192.0 \pm 35.1$ & $253.0 \pm 37.4^{*}$ & $139.8 \pm 17.5$ & $129.0 \pm 21.3$ & $101.0 \pm 33.0^{*}$ & $129.2 \pm 19.8$ \\
S & $11.25 \pm 0.47$ & $17.25 \pm 0.47^{*}$ & $13.00 \pm 2.48$ & $9.50 \pm 0.95^{*}$ & $11.25 \pm 1.93$ & $10.5 \pm 1.44^{*}$ \\
E & $6.34 \pm 00.65$ & $8.22 \pm 0.87$ & $6.33 \pm 1.07$ & $5.52 \pm 0.42$ & $7.27 \pm 0.65$ & $5.42 \pm 0.59$ \\
\hline
\end{tabular}
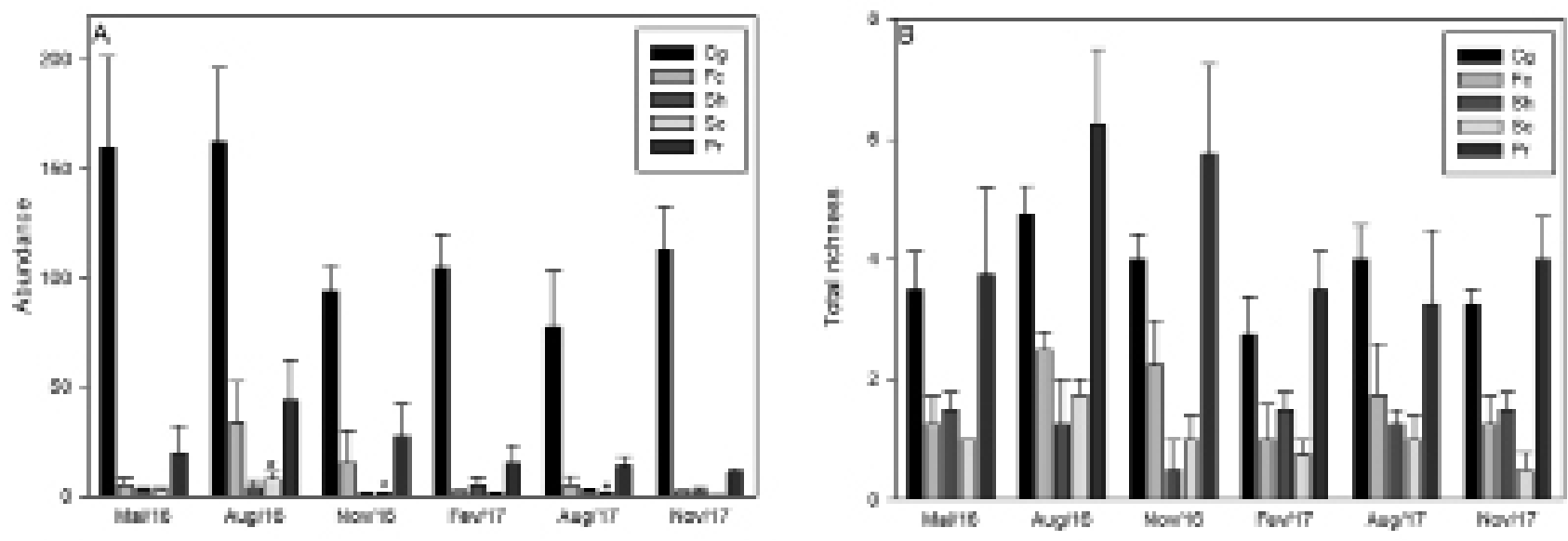

Fig. 2. Abundance (A) and Total Richness (B) (mean \pm SEM) of functional feeding groups of the benthic macroinvertebrates for different seasons in the Das Fêmeas stream, São Desidério, BA, Brazil (Cg, Collector-gatherer; Fc, Filter-collector; Sh, Shredder; Sc, Scraper; Pr, Predator). * Indicate significant differences between substrates $(\mathrm{p}<0.05)$.

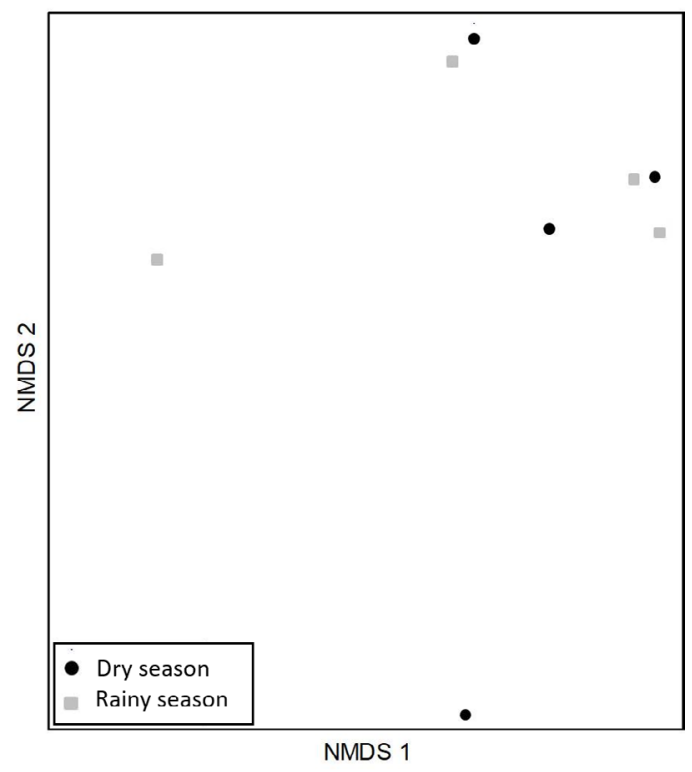

Fig. 3. NMDS analysis between seasons and composition of the benthic macroinvertebrates assemblage in the Das Fêmeas stream, São Desidério, BA, Brazil.

\section{DISCUSSION}

In the current study, the different seasons did not influence the composition of benthic macroinvertebrates, which does not corroborate the hypothesis that the seasons differ in terms of organism composition. It appears that season is less important in determining the composition of these macroinvertebrates in tropical streams (PEREIRA et al., 2017), although the hydrological regime is higher in the rainy season (PIo et al., 2018). In addition, a high precipitation was verified in the summer, with no rainfall in the winter. So, the projection that the Taxa richness would be higher in the dry period was confirmed. However, the same did not occur for the other diversity indices (Shannon-Wiener diversity, Pielou equitability, rarefied richness and abundance), only partially confirming the hypothesis of this study.

A possible explanation for the lower richness found in the rainy season in our study is due to the fact that in the rainy season, some taxonomic groups do not remain in the assemblage due to alterations in the microhabitats, in feeding and in the physical drag and movement of the organisms (BISPO et al., 2001). In this way, previous studies in tropical 
Cerrado ecosystems have verified that the seasonal rainfall regime is essential in the temporal variation of associations of benthic macroinvertebrates in streams (OliveIRA et al., 1999; Ribeiro \& UiedA, 2005). Despite this, it cannot be confirmed that there is a seasonal pattern regarding the richness of benthic macroinvertebrates in tropical streams. Although some previous studies have found a greater Taxa richness in the dry season (BAPTISTA et al., 2001; CALLISTO et al., 2005), other studies did not verify differences in this richness between the dry and rainy seasons (PEREIRA et al., 2017; Pio et al., 2018).

In this study, the taxon with the highest number of individuals was Chironomidae, which can be attributed to the great adaptability and competitiveness of these individuals (Di Giovanni et al., 1996), as well as the availability of food resources such as allochthonous organic matter (MARQUES et al., 1999; Oliveira \& Nessimian, 2001). Similarly, the dominance of Chironomidae has also been verified in previous studies in Cerrado ecosystems (GALDEAN et al., 2001), ecotones between Atlantic forest and Cerrado (CARValho \& Uieda, 2004; Ribeiro \& Uieda, 2005), as well as in other ecosystems in northeastern Brazil (PEREIRA et al., 2017; PIo et al., 2018). Additionally, the FFG with the highest abundance and richness in this study were collectorgatherers and predators respectively. The occurrence of predators may be explained by the high supply of prey, i.e. collector-gatherers and other FFG (CоPATTI et al., 2013). The high abundance of collector-gatherers might be due to the high contribution of allochthonous material, where the input of organic matter from riparian vegetation represents a higher energy value than algae and aquatic weeds (LinARES et al., 2013). Despite this, FFG did not differ in abundance or richness between seasons in the present study.

The stability in the abundance of individuals between the different seasons can be explained by the substitution of taxa, where the biological communities adapt to gradients according to the environmental changes, mainly rainfall (PIO et al., 2018). In addition, the increase in the supply of allochthonous material in the environment in the rainy season contributes to the increase of available food resources (CAllisto et al., 2001), with consequent mitigation of negative impacts of higher water flow on abundance of organisms. In addition, some taxa can present strategies to withstand the disturbances promoted by the water flow (WOODWARD et al., 2015) and other groups reproduce more frequently and allow for recolonisation of the environment in the rainy season (BonADA et al., 2007).

The distribution pattern of benthic macroinvertebrates between the seasons can vary due to different regional seasonal patterns, as well as due to differences in relation to stability and resilience of colonisation after rainfall in tropical streams (NAvA et al., 2015). However, in this study, the composition of the benthic macroinvertebrate assemblage was similar between the dry and rainy seasons, which were supported by the results of the NMDS analysis. This demonstrates that seasonal variations occurred in this tropical stream, with consequent reduction of species richness in the rainy season; do not substantially alter the abundance and composition of the benthic macroinvertebrate assemblage. Therefore, benthic macroinvertebrates can adapt according to the seasonal changes. So, a possible contribution of our findings is that future biomonitoring studies should devote more time to evaluations of anthropogenic actions and their environmental consequences in tropical streamsthan to seasonal variations in the composition of benthic macroinvertebrates.

\section{REFERENCES}

Baptista, D. F.; Dorvillé, L. F. M.; Buss, D. F. \& Nessimian, J. L. 2001. Spatial and temporal organization of aquatic insects assemblages in the longitudinal gradient of a tropical river. Revista Brasileira de Biologia 61(2):295-304.

Bispo, P. C.; Oliveira, L. G.; Crisci, V. L. \& Silva, M. M. 2001. A pluviosidade como fator de alteração da entomofauna bentônica (Ephemeroptera, Plecoptera e Trichoptera) em córregos do Planalto Central do Brasil. Acta Limnologica Brasiliensia 13(2):1-9.

Bonada, N.; Doledec, S. \& Statzner, B. 2007. Taxonomic and biological trait differences of stream macroinvertebrate communities between mediterranean and temperate regions: Implications for future climatic scenarios. Global Change Biology 13(8):1658-1671.

Callisto, M.; Goulart, M.; Medeiros, A. O.; Moreno, P. \& Rosa, C. A. 2005. Diversity assessment of benthic macroinvertebrates, yeasts, and microbiological indicators along a longitudinal gradient in Serra do Cipó, Brasil. Brazilian Journal of Biology 64(2):743-755.

Callisto, M.; Moretti, M. \& Goulart, M. 2001. Macroinvertebrados bentônicos como ferramenta para avaliar a saúde de riachos. Revista Brasileira de Recursos Hídricos 6(1):71-82.

Carvalho, E. M. \& UiedA, V. S. 2004. Colonização por macroinvertebrados bentônicos em substrato artificial e natural em um riacho da serra de Itatinga, São Paulo, Brasil. Revista Brasileira de Zoologia 21(2):287293.

Copatti, C. E.; Ross, M.; Copatti, B. R. \& Seibel, L. F. 2013. Bioassessment using benthic macroinvertebrates of the water quality in the Tigreiro river, Jacuí Basin. Acta Scientiarum, Biological Sciences 35(4):521529.

Cummins, K. W.; Merritt, R. W. \& Andrade, P. C. N. 2005. The use of invertebrate functional groups to characterize ecosystem attributes in selected streams and rivers in south Brazil. Studies on Neotropical Fauna and Environment 40(1):69-89.

Di Giovanni, M. V.; Goretti, E. \& Tamanti, V. 1996. Macrobenthos in Montedoglio reservoir, central Italy. Hydrobiologia 321(1):17-28.

Domínguez, E. \& Fernández, H. R. 2009. Macroinvertebrados bentónicos sudamericanos: Sistemática y Biología. San Miguel de Tucumán, Fundación Miguel Lillo. 654p.

Dudgeon, D. \& Wu, K. K. Y. 1999. Leaf litter in a tropical stream: Food or substrate for macroinvertebrates? Archiv für Hydrobiologie 146(1):65-82.

Esteves, F. A.; Leal, J. J. F. \& Callisto, M. 2011. Comunidade bentônica In:Esteves, F. A. Fundamentos de limnologia. 3ed. Rio de Janeiro, Interciência, p. 581-603.

Galdean, N.; Callisto, M. \& Barbosa, F. A. R. 2001. Biodiversity assessment of benthic macroinvertebrates in altitudinal lotic ecosystems of Serra do Cipó (MG, Brazil). Revista Brasileira de Biologia 61(2):239-248.

InMet - Instituto Nacional de Metereologia. 2017. Boletim agroclimatológico. Distrito Federal, Brasil. Available at $<$ https:// www.inmet.gov.br/portal/index.php?r=agrometeorologia/ boletimAgroclimatologico $>$. Accessed on 28 May 2020.

KiKuchi, R. M. \& UiedA, V. S. 2005. Composição e distribuição dos macroinvertebrados em diferentes substratos de fundo de um riacho no município de Itatinga, São Paulo, Brasil. Entomología y Vectores 12(2):193-231.

LAKE, P. S. 2000. Disturbance, patchiness, and diversity in streams. Journal of the North American Benthological Society 19(4):573-592. 
Linares, M. S.; Faccioli, G. G. \& Freitas, L. M. 2013. Functional structure of benthic community in a tropical stream in northeast Brazil: Seasonal variation. Revista Brasileira de Zoociências 15(1-3):147-154.

LоBо, H. A. S. 2013. Circulação microclimática entre superfície, grandes dolinas e cavernas no carste de São Desidério, Bahia. Sociedade e Natureza 25(1):163-178.

Marques, M. M. G. S. M.; Barbosa, F. A. R. \& Callisto, M. 1999. Distribution and abundance of Chironomidae (Diptera, Insecta) in an impacted watershed in South-east Brazil. Revista Brasileira de Biologia 59(4):553-561.

Melo, A. S. 2009. Explaining dissimilarities in macroinvertebrate assemblages among stream sites using environmental variables. Zoologia 26(1):79-84.

Nava, D.; Restello, R. M. \& HePp, L. U. 2015. Intra- and inter-annual variations in Chironomidae (Insecta: Diptera) communities in subtropical streams. Zoologia 32(3):207-2014.

Nessimian, J. L.; Venticinque, E. M.; Zuanon, J.; De-Marco, P.; Gordo, M.; Fidelis, L.; Batista, J. D. \& Juen, L. 2008. Land use, habitat integrity, and aquatic insect assemblages in Central Amazonian streams. Hydrobiologia 614(1):117-131.

Oliveira, A. L. H. \& Nessimian, J. L. 2001. Aquatic macroinvertebrate diversity and composition in streams along an altitudinal gradient in Southeastern Brazil. Biota Neotropica 10(3):115-128.

Oliveira, L. G.; Bispo, P. C.; Crisci, V. L \& Souza, K. G. 1999. Distribuições de categorias funcionais alimentares de larvas de Trichoptera (Insecta) em uma região serrana do Brasil Central. Acta Limnologica Brasiliensia 11(2):173-183.

Peiró, D. F. \& Alves, R. G. 2006. Aquatic insects associated with macrophytes of litoral region of Ribeirão das Anhumas reservoir (Américo Brasiliense, São Paulo State, Brazil). Biota Neotropica 6(2):1-9.

Pereira, T. S.; Pio, J. F. G.; Calor, A. R. \& Copatti, C. E. 2017. Can the substrate influence the distribution and composition of benthic macroinvertebrates in streams in northeastern Brazil? Limnologica 63(1):27-30.

Pimentel, A. L.; Aquino, R. F.; Silva, R. C. A. \& Vieira, C. M. B. 2000. Estimativa da recarga do aquifero Urucuia na sub-bacia do rio das Fêmeas - Oeste da Bahia, utilizando separação de hidrogramas. In: Congresso sobre aproveitamento e gestão de recursos hídricos em países de idioma português. Rio de Janeiro, ABES/AIDIS/ABRH, p. 27-37.

Pio, J. F. G.; Pereira, T. S.; Calor, A. R. \& Copatti, C. E. 2018. Organisation of the benthic macroinvertebrate assemblage in tropical streams of different orders in North-Eastern Brazil. Ecología Austral 28(1):113-122.

Ribeiro, L. O. \& Uieda, V. S.2005. Estrutura da comunidade de macroinvertebrados bentônicos de um riacho de serra em Itatinga, São Paulo, Brasil. Revista Brasileira de Zoologia 22(3):613-618.

Salles, F. F. \& Ferreira-Junior, N. 2014. Hábitat e hábitos. In: Hamada, N.; Nessimian, J. L. \& Querino, R. B. ed. Insetos aquáticos na Amazônia brasileira: Taxonomia, biologia e ecologia. Manaus, INPA, p. 39-49.

Silveira, M. P.; Buss, D. F.; Nessimian, J. L. \& Baptista, D. F. 2006. Spatial and temporal distribution of benthic macroinvertebrates in a Southeastern brazilian river. Brazilian Journal of Biology 66(2):623632.

Tundisi, J. G. \& Matsumura-Tundisi, T. 2008. Limnologia. São Paulo, Oficina de Textos. 631p.

Woodward, G.; Bonada, N.; Feeley, H. B. \& Giller, P. S. 2015. Resilience of a stream community to extreme climatic events and long-term recovery from a catastrophic flood. Freshwater Biology 60(12):24972510.

WriGHT, K. K. \& LI, J. L. 2002. From continua to patches: Examining stream community structure over large environmental gradients. Canadian Journal of Fisheries and Aquatic Sciences 59(8):1404-1417. 